\title{
SCOLIOSIS SECONDARY TO PARAPLEGIA
}

\author{
By ROBERT ROAF \\ Professor of Orthopaedic Surgery, University of Liverpool
}

METHODS of preventing deformity at the site of a spinal injury are now well established (Guttmann, I953, I963; Frankel et al., 1969). Nevertheless there is a risk of a secondary spinal deformity developing below the level of the spinal injury, unless steps are taken to prevent this. Scoliosis in association with spastic paraplegia due to tumours or abiotrophies has been recognised for many years (Tachdjian \& Matson, I965) but it is only in the last 20 years that the improved prognosis for life in young paraplegics has lead to a wider recognition of scoliosis secondary to traumatic paraplegia.

It seemed probable that a more detailed study of the anatomy of the deformity and a comparison between deformities secondary to traumatic paraplegia, deformities due to spinal cord diseases, those due to cerebral paraplegia and deformities of unknown aetiology, would prove of value. This study has thrown some light on the mechanisms which lead to the development of scoliosis. This, in its turn, has led to a better understanding of methods of preventing the onset of spinal deformity in paraplegia at levels below the original level of injury. It is to be expected that such deformities will not be seen in the future, this is, therefore, an appropriate time to present the relevant data.

In this survey six patients had to be discarded because the data were inadequate, and in eight others there were other anomalies apart from the paraplegia and although I thought that the scoliosis was due to the paraplegia, as there was a possibility that other factors might be operating, they were discarded from the survey. For example, patients with spastic paraplegia and congenital spinal anomalies at a higher level than the deformity were discarded.

Table I presents the basic data for 12 patients with traumatic paraplegia. As might be expected the apex of deformity was usually in the thoraco-lumbar region, but in some cervical spine injuries the deformity was at a higher level.

Table II presents the data in six patients with paraplegia secondary to spinal disorders-that is either tumours or abiotrophies.

Table III presents the data in six patients with paraplegia secondary to hydrocephalus of acquired origin, e.g. secondary to basal meningitis or tumours.

Table IV presents the data in Io patients with scoliosis secondary to cerebral palsy. In none of these patients was there any evidence of asymmetrical or impaired function of the intercostal muscles or diaphragm, so it would appear that the scoliosis was due to asymmetrical action of the postural muscles of the trunk.

Patient 5 in Table I is of interest as he developed an early, but still relatively mild, scoliosis which disappeared following anterior root section of the ist lumbar to Ist sacral roots, which was performed for spastic contracture of his legs. There has been no recurrence of the spinal deformity.

In patient 3, Table I, there occurred first a dislocation of the right hip due to unbalanced muscle action. This was treated by open reduction and a psoas transplant. Later a scoliosis convex to the left-that in the weaker side- 
spinaı injuries

\begin{tabular}{|c|c|c|c|c|c|c|c|c|c|}
\hline Patient & Sex & $\begin{array}{c}\text { Age } \\
\text { at } \\
\text { onset }\end{array}$ & $\begin{array}{c}\text { Age } \\
\text { at } \\
\text { assessment }\end{array}$ & $\begin{array}{c}\text { Level } \\
\text { of } \\
\text { lesion }\end{array}$ & $\begin{array}{c}\text { Angles } \\
\text { of } \\
\text { curves }\end{array}$ & $\begin{array}{c}\text { Angle } \\
\text { of } \\
\text { rotation }\end{array}$ & $\begin{array}{l}\text { Level } \\
\text { of } \\
\text { apex }\end{array}$ & Length & Comments \\
\hline I. J. J. & M & 15 & $3 I$ & Tio & 45 & 30 & LI & 6 & \\
\hline 2. P. F. & M & 6 & IO & $\mathrm{T}_{5}$ & 50 & 60 & LI & 6 & \\
\hline 3. D. D. & $\mathrm{F}$ & 4 & 9 & $\mathrm{~T} 8$ & 45 & 30 & L2 & 5 & Partial recovery \\
\hline 4. J. V. & $\mathrm{F}$ & 9 & II & C6 & 60 & 25 & $\mathrm{~T}_{7}$ & 7 & \\
\hline 5. B. M. & M & I I & I9 & $\mathrm{C}_{7}$ & $\begin{array}{c}\text { Less } \\
\text { than } \\
20\end{array}$ & 20 & LI & 5 & $\begin{array}{l}\text { Anterior root } \\
\text { section }\end{array}$ \\
\hline 6. J. P. & M & 8 & 17 & T6 & 30 & 30 & LI & 4 & \\
\hline 7. S. L. & $\mathrm{F}$ & 4 & 20 & $\mathrm{~T} 2$ & 58 & 30 & LI & 5 & \\
\hline 8. A. P. & M & I4 & 20 & $\mathrm{~T}_{3}$ & 25 & 30 & LI & 4 & \\
\hline 9. N. R. & M & Birth & I8 & Cervical & 105 & 55 & $\mathrm{~T}_{7}$ & 8 & \\
\hline Iо. J. B. & $\mathrm{F}$ & IO & IO & Cervical & 120 & 45 & $\mathrm{~T}_{7}$ & I I & $\begin{array}{l}\text { Assoc. brachial } \\
\text { plexus lesion }\end{array}$ \\
\hline II. J. P. & $M$ & 15 & $2 \mathrm{I}$ & $\mathrm{T}_{3}$ & 30 & IO & $\mathrm{T} 8$ & 8 & \\
\hline I2. B. B. & $M$ & Birth & I4 & Cervical & 80 & 45 & Tio & 8 & \\
\hline
\end{tabular}

TABLE II

Spinal Disease

\begin{tabular}{|c|c|c|c|c|c|c|c|c|}
\hline Patient & Sex & $\begin{array}{l}\text { Age at } \\
\text { onset }\end{array}$ & $\begin{array}{c}\text { Age at } \\
\text { assessment }\end{array}$ & Type and level of lesion & $\begin{array}{l}\text { Angles of } \\
\text { curves }\end{array}$ & $\begin{array}{l}\text { Angle of } \\
\text { rotation }\end{array}$ & $\begin{array}{l}\text { Level of } \\
\text { apex }\end{array}$ & Length \\
\hline I. R. J. & $M$ & 2 & I9 & Spinal tumour & I 34 & 90 & $\mathrm{~L}_{2}$ & 7 \\
\hline 2. D. C. & M & 12 & I8 & Syringomyelia & 90 & 35 & LI & 7 \\
\hline 3. M. C. & $\mathrm{F}$ & IO & 20 & Syringomyelia & II5 & 90 & TI2 & 8 \\
\hline 4. J. H. & M & 8 & I4 & Syringomyelia & 90 & 75 & TI2 & 8 \\
\hline 5. J. Q. & M & 7 & I4 & Cervical syringomyelia & 59 & 45 & T6 & 7 \\
\hline 6. J. F. & $\mathrm{F}$ & 2 & II & Neuroblastoma $\mathrm{T}_{4}$ & 140 & 90 & TII & 5 \\
\hline
\end{tabular}


TABLE III

Scoliosis Secondary to Hydrocephalus

(Excluding patients with associated congenital spinal abnormality)

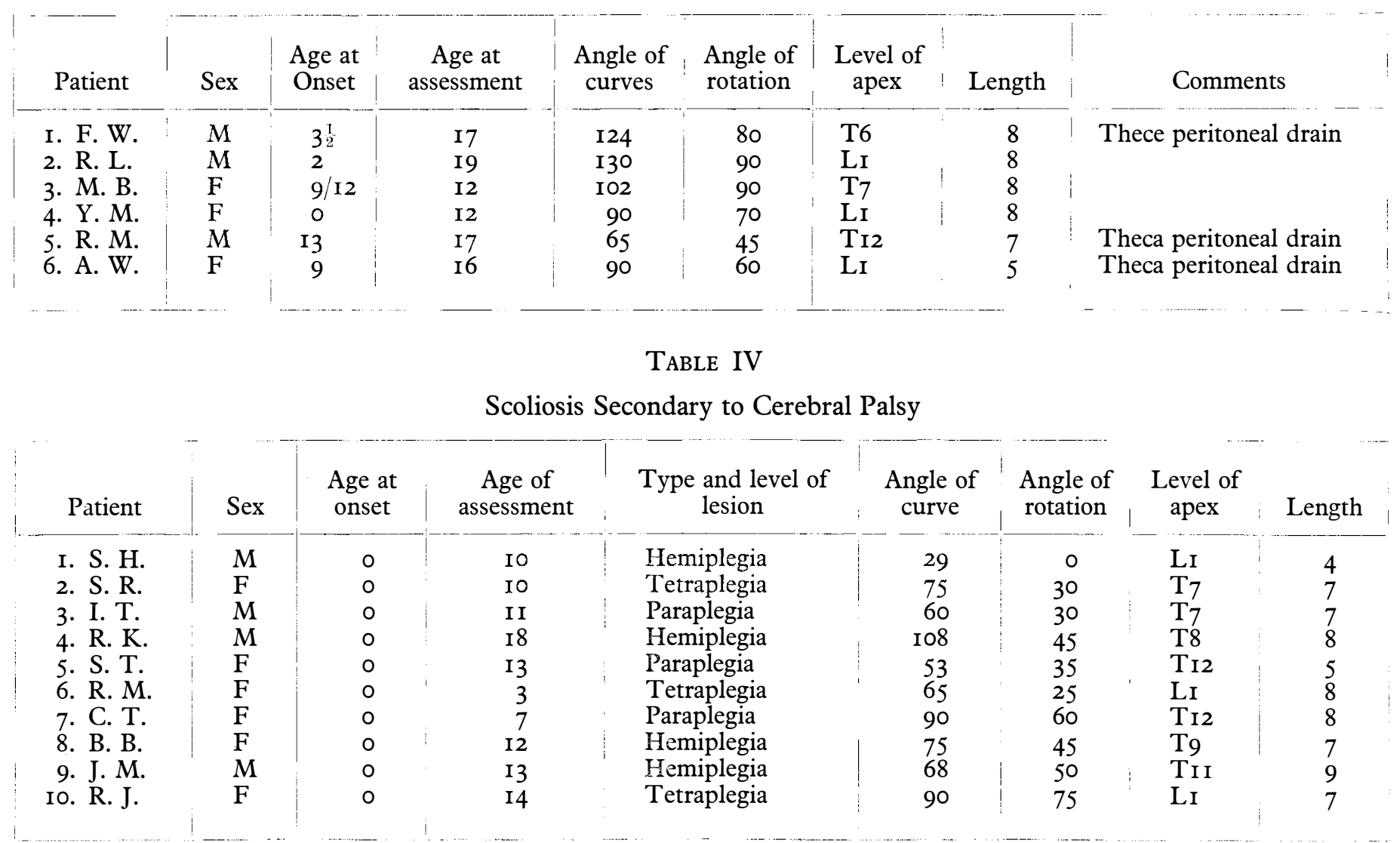


developed. This was improved by resection of some of the spinal muscles on the right-that is the more spastic side. This patient ultimately made considerable neurological improvement and managed to walk independently. It was during the phase of improvement that the deformity occurred. Probably more energetic physiotherapy at this stage could have prevented this.

From the data it appears that paraplegic scoliosis is primarily due to unequal action of the postural muscles of the trunk, particular the rotator muscles of the

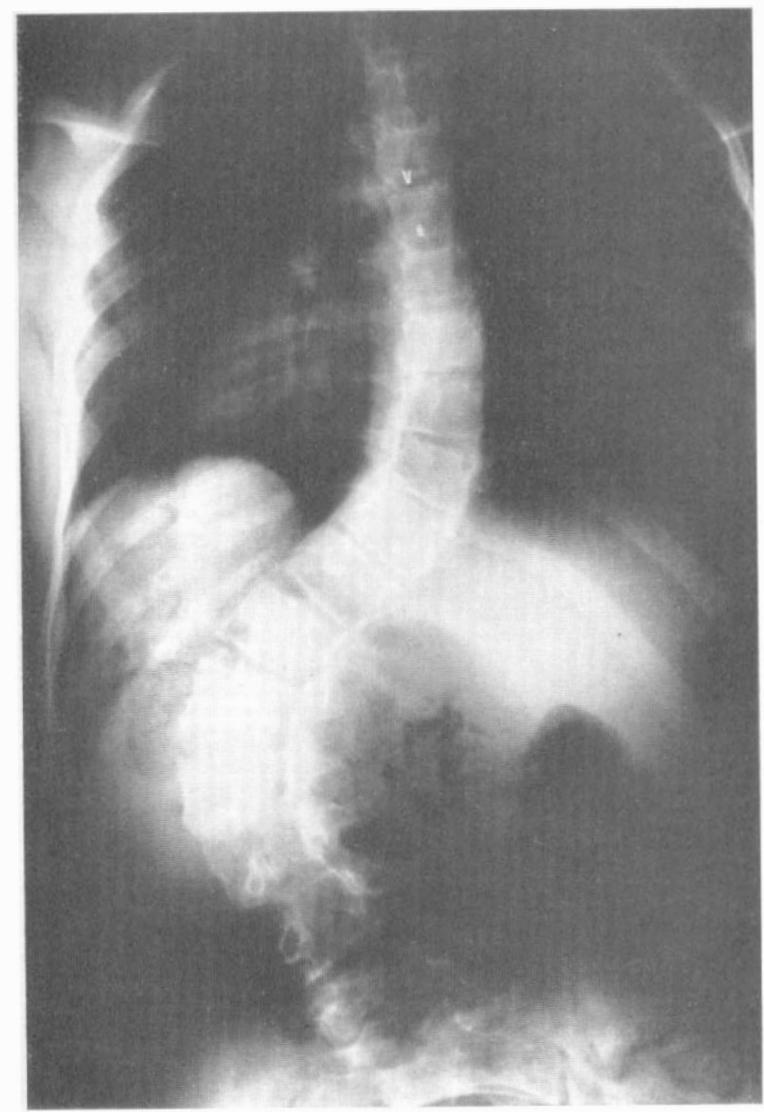

FIG. I

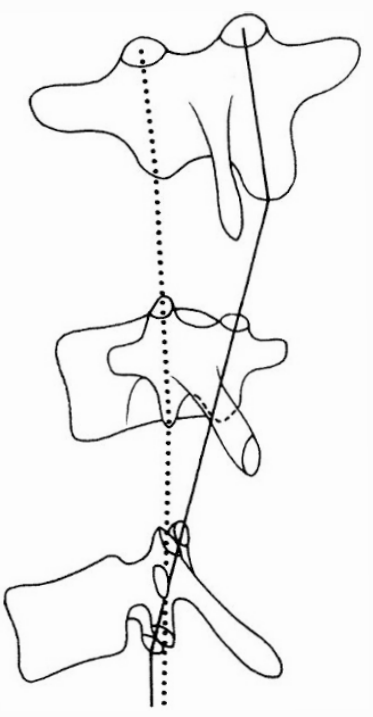

FIG. 2

Fig. I.-Scoliosis secondary to spastic paraplegia. Note extreme rotation.

Fig. 2.-Diagram to illustrate varying inclination of articular facets. Lateral view of scoliotic spine. Continuous line is line of facets on convex side. Dotted line is line of facets on concave side.

erector spinae, and in the early stages treatment directed to these muscles can mitigate the deformity. Later, if the deformity is untreated changes occur in the shape of the bones due to interference with growth. These changes are identical with those found in scoliosis due to other causes-namely there is, first, deficient growth of the articular processes on the concave side, then there is hypoplasia of the laminae on this side, followed later by excessive growth of the bodies and intervertebral discs on the convex side.

As in other forms of scoliosis, the rotation which was often extreme (fig. I), was due to asymmetrical inclination of the articular facets above and below the 
apical vertebrae - that is the line joining the facets on the concave side below the lesion runs upwards and forwards, whereas a similar line joining the facets on the convex side runs upwards and backwards and vice versa in the vertebrae above the apex (fig. 2). In general, scoliosis with paraplegia and so-called idiopathic scoliosis present very similar clinical, radiological and anatomical pictures (fig. 3). Adults who develop trunk deformities secondary to neurological lesions such as disorders

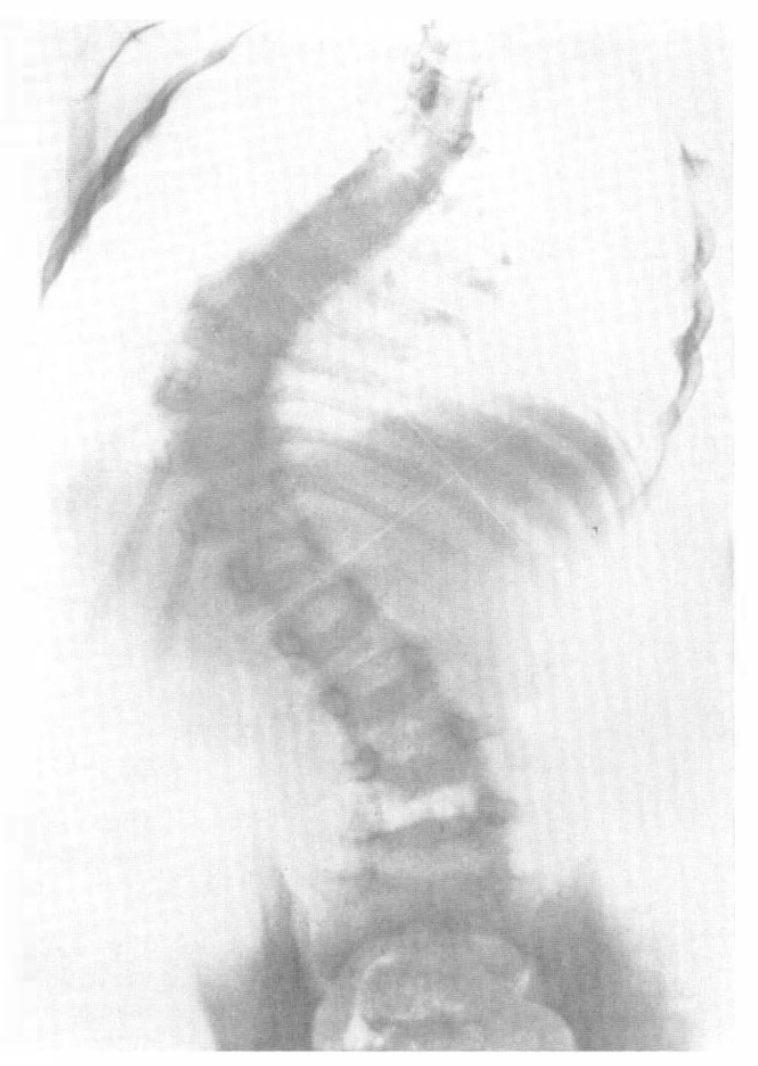

FIG. 3

Progressive scoliosis secondary to unilateral spasticity.

of the basal ganglia, rarely show marked changes in bone shape and severe scoliotic deformities with alteration in bone shape do not occur in adult paraplegics.

If these spinal deformities are allowed to occur they may have serious consequences leading to difficulties in sitting, standing, driving a car and participating in other recreations; in other words, they seriously interfere with normal paraplegic rehabilitation and predispose to unilateral sores.

As one would expect, scoliosis secondary to asymmetrical action of the postural trunk muscles has its maximum incidence in the lower thoracic and upper lumbar regions, as contrasted to scoliosis secondary to asymmetrical rib action, which has its maximum incidence in the upper- and mid-thoracic zones. 


\section{SUMMARY}

Details are given of young patients with scoliosis secondary to spastic paraplegia. There is evidence that the mechanism of deformity is asymmetrical action of the trunk postural muscles, particularly the deep oblique spinal muscles. Untreated, this leads to alteration in the shape of the vertebra. Treatment directed to abolishing such asymmetrical action can mitigate the deformity and prevention of such deformities is an important element in the rehabilitation of paraplegics.

\section{RÉSUMÉ}

Des détails sont donnés en ce qui concerne les jeunes malades atteints d'une scoliose secondaire à une paraplégie spastique. Il y a une évidence que le mécanisme de la difformité est une action assymétrique des muscles posturaux du tronc, en particulier les muscles spinaux obliques profonds.

Sans traitement, ceci donne une altération de la forme de la vertèbre.

Un traitement dirigé en vue d'abolir cette action assymétrique peut réduire la difformité et prévenir la déformation, élément important dans la rééducation du paraplégique.

\section{ZUSAMMENFASSUNG}

Einzelheiten von jungen Patienten mit Skoliosis als Folge von spastischer Paraplegie werden beschrieben. Es wird bewiesen, dass der Mechanismus der Deformität auf der asymmetrischen Aktion der posturalen Rumpfmuskeln, besonders der tiefen schrägen Spinalmuskeln beruht. Ohne Behandlung führt dies zu einer Veränderung der Form der Wirbelsäule. Die Behandlung, gezielt auf die Aufhebung solcher asymmetrischen Aktion, kann die Deformitäten mildern und Verhütung solcher Deformitäten ist ein wichtiges Element in der Rehabilitation von Paraplegikern.

\section{REFERENCES}

Frankel, H. L., Hancock, D. O., Hyslop, G., Melzak, J., Michaelis, L. S., Ungar, G. H., VERNON, J. D. S. \& WALSH, J. J. (I969). The value of postural reduction in the initial management of closed injuries of the spine with paraplegia and tetraplegia. Paraplegia, 7, I 79-192.

GuttmanN, L. (1953). In Medical History of the Second World War, Surgery, ed. Cope, Z., p. 422. London: H.M. Stationery Office.

Guttmann, L. (1963). Proceedings of a Symposium on Spinal Injuries, pp. Ior-I I2. Royal College of Surgeons of Edinburgh.

TACHDJiAN, M. O. \& MATSON, D. D. (1965). Orthopaedic aspects of intra-spinal tumours in infants and children. Fournal of Bone and foint Surgery, 47-A, 223-248. 